\title{
AN ERROR ANALYSIS OF STUDENTS IN WRITING NARRATIVE TEXT
}

\author{
Juliani Dameria Pardosi ${ }^{1}$ \\ Universitas Prima Indonesia \\ Renstra EmithaVeronika Br. Karo ${ }^{2}$ \\ Universitas Prima Indonesia \\ Owinike Anggun S. Sijabat ${ }^{3}$ \\ Universitas Prima Indonesia \\ Hotmatua Pasaribu ${ }^{4}$ \\ Universitas Prima Indonesia \\ Natalia Widya Pasca Tarigan ${ }^{5}$ \\ Universitas Prima Indonesia \\ juliani.d.pardosi@gmail.com ${ }^{1}$ \\ Submit, 27-11-2019 Accepted, 21-12-2019 Publish, 25-12-2019
}

\begin{abstract}
This research is aimed to find out the typical errors on students in writing narrative text by using simple past tense at grade IX of SMP SwastaTalitakum Medan. The researchers used a descriptive qualitative method in this research. Based on the research findings, it can be concluded that the errors of misinformation are the most frequent errors in which the ninth grade students committed 233 errors in regular verb. Moreover, it was followed by errors of misinformation with 150 errors, addition with 38 errors, omission with 29 errors and misordering with 16 errors. Then errors in regular verb, it was followed by errors of misordering with 36 errors, omission with 38 errors, addition with 56 errors and misinformation with 156 errors. It can be concluded that after analyzing through the research, the writer got the data about students' errors, which are commonly made in narrative writing using simple past. Their errors are misinformation, addition, omission and misordering.
\end{abstract}

Keywords: error analysis, simple past tense

\section{INTRODUCTION}

Nowadays English becomes one of the most important language subject of education for students in Indonesia because they learn English from elementary level up to universitylevel.Through Englishstudents are hoped to have ability in communication in English. 
Writing is the most difficult skill in English for students. It is differentfrom learning other skill because writing is thinking process ,So it can help peopleto deepen their understanding.

Pattel and Jain (2001) said "writing is essential features in learning a language because it provides a very good means of foxing the vocabulary,spelling and sentence pattern". According to Nunan (2001) there are otherimportant differences as well. Writing, unlike speech, is displaced in time, since itmakes possible the transmission of message from one place to another.Meanwhile Linse (2005) stated that writing is a combination of process and product.

Writing has several genre one of which is Narrative. Narrative is telling of some true or factious event or connected sequence of events. Simple past tense is used in narrative writing because the narration is writing about sucession of event in the past.

Learning english is different from learning Bahasa Indonesia. Students who learn English may produce many error in their writing such as in tenses or in arrange sentence become agood paragraph. Harmer (2007) states "students go on making the same mistake even when those mistake have been repeadly pointed out of them. An Error analysis has an important role to reveal what kind of error the students do. The students will not do the same error or make some errors repeadly.

Based on statement above, students as beginners in learning English usually make error in writing as learning process. For example in writing narrative text, students have to know the aspect of the text such as grammatical features and generic structure in narrative text.

So, production writing have important roles, to approach skill the students in writing. Based on the statement above, the writer will discuss " error analysis of students' in writing narrative text in senior high school ". And the writer makeuse the test to find students' error in writing of narrative text.

Sattayatham \& Ratanapinyowong (2008) stated that most students understood the story in the passage they had read, and understood what they were asked to write but they had problems with the format of paragraph writing. They wrote an opinion paragraph with no introduction, no topic sentence, and no transitional words. In addition, the paragraph was incoherent and lacks organization. Moreover, they placed too much emphasis on presenting their ideas and disregarded the conclusion. Therefore, a conclusion was often missing in the medical students' opinion paragraph writing. Finally, most students also had difficulty in using English grammar. Error analysis plays an important role in this aspect because it can help in students' error recognition and thus aid students in writing good paragraphs after they learn how to correct these errors through practices. 
Andrew (2014) stated that the process of writing is the best solution to reduce the number of mistakes made by students. This is because the process approach has been accepted and applied to EFL and ESL writing classes because of its effectiveness. The benefit of the process approach is to allow students handle their own writing by giving them an opportunity to contemplate as they write that is, students transmit their messages to the readers in written form through the complex writing process; pre-writing, drafting, revising, editing, and publishing. Within the process, they keep revising their writing and instinctively center more on errors made in syntax, grammar, vocabulary, meaning, punctuation, and spelling. Second, while producing different types of academic prose-writing, they are permitted to acquire grammatical accuracy in the revising stage or in the circumstances of peer evaluations and cooperative learning, for instance, narrating a story to each other in the writing process. To conclude, by adopting the above-mentioned strategies, the learners ${ }^{\text {ee }}$ writing skills will be improved and subsequently reduce the chance of making errors. It is hoped that this paper can enlighten the English.

Herlinawati (2011) explained that in writing narrative text, the teachers should be clearly explain the irregular verbs to the students. Then the teachers should be creative in teaching narrative text as there are some rules to be made in writing narrative text. Besides of that, English teachers must be able to motivate the students as English is still foreign language in Indonesia.

Susanti (2017) explained that the correlation between result of reseacher's finding and previous study, there were discussed the importance of error analysis are the method could help English teacher found the next media or technique to teach writing and help students if the students found difficulties in made paragraph. The theory was supposed by the previous study that described about error analysis had important role to find a solution by the teacher about what the students to do next in explaining the material especially writing paragraphs and for the students of error analysis could be used material correction of students' task. Therefore, if having writing narrative text tasks, the students did not make same mistake.

Based on the explanation above, the writers would like to analyze the students' errors in writing narrative text focusing on the errors of Addition, Omission, Misordering, and Misinformation. Four of these aspects are very important to be noted by students in writing narrative text. After conducting the research, the writers would like to explain more about how to write narrative text well to the students. 


\section{LITERATURE REVIEW Writing Skills}

The process of learning the students will be find something wrong or mistake. The making of error can "tbe avoided in learning process. Analysis is the most important a method to get information about the function of cognitive process in language production and language perception. One of analysis that can detect studentse error is error analysis.

Error analysis is the study of learner error, providing the way to examine learner language, being a part of language teaching, finding out whether errors were caused by first language interference or developmental factors (Bootchuy (2008).

\section{Error and Mistake}

Learning the second language is different from learning first language. Therefore, the students often made error while the teaching learning process. For the foreign language, the students can get a new rules of language, vocabulary, grammatical patterns and pronunciations which different from language. The error is natural for the students in learning the second language, because english is the second language for students.

Taylor (1997) said that In science, the word error does not carry the usual conotation of term mistakes or blunder. Error in a scientific measurmentmeans the inevitable uncertainty that attends all measurment. According to Brown (2000) errors is a noticeable deviation from the adult grammar of a nativespeaker, reflecting the interlanguage competence of the learner. Mean while Spillner (1991) said error in the second language are evidence for exitinglanguage contrast and hence for learning difficulties.

It means that there is something wrong in norms of language performance; the making of errors is so unavoidable in learning process. Besides, the making oferrors is one part of learning and no one can learn without making errors.Error may happen in teaching learning process. It is partly becauseteachers lack in grammar competences As a result students have differentunderstanding or wrong perception then they keep in their brain.

According to Corder (1981) mistakes are no significant to the processof language learning. However, the problem of determining what is learner"esmistake and what a learneres error is one of some difficulty. It involves a muchmoreshopisticated study and analysis of error usually accorded them. Meanwhile, Edge (1997) said the most important mistake are those which affect meaningand communication and mistake that affect a long stretch of language are moreimportant than mistake which have only local mistakes. 
In the other Hand Harmer (2007) said mistake is devided into threebroad categories : „slips ${ }^{e e}$ (mistake which they can correct themselves once themistakes has been pointed out to them), „error ${ }^{\text {ee }}$ (mistake which they can "tcorrectthemselves, and which therefore need explanation), attempts (that is when astudents tries to say something but does not yet know the correct way of saying it)Based on statement above It can be concluded that if the student know therule, but they make mistake, It's called slip. In contrast, if students doesn "tknowand make mistake, It"s called error..

\section{Types of Error}

The error of learners can be classified as the errors of competence and the errors of performance. The errors of competence are systematic and continuously. Otherwise, errors of performance are unsystematic, and the students can correct by themselves. To describe the type of error, Dulay et.al (1982) said that there are four types of error.

Many errors of taxonomy have been classified based on the linguistic item, while is affected by an error. These linguistics category taxonomies classify errors according to either of both the language component and the particular linguistic constituent the errors effect.

Language component include Phonology (pronunciation), syntax and morphology (grammar), semantic and lexicon (meaning and vocabulary), and discourse (style). Constituents include the elements that comprise of each language components. For example, within syntax one may ask whether the error is in the main or subordinate clause: within a clause, which constituent are affected, e.g. the noun phrase, the auxiliary, the verb phrase, the preposition, the adverbs, the adjective and so forth.

Surface strategy of taxonomy of highlight the ways surface a surface a structure are altered: Students may omit necessary items (omission) or add unnecessary ones (addition) they may misinformation items (selection) or misorder them (misordering). (1) Omission errors are characteristic by the absence of an item that must be appear in a well-formed utterance, although any morpheme or word in a sentence is a potential candidate for omission, some types of morphemes are omitted more than other.For example: Budi headmaster new school.

Addition errors are opposite of omissions. They are characterized by the presence of an item, which must not appear in a well-formed utterance. There are types of addition of errors: (1) Double markings: she didn't went back. (2) Regularization: ated for ate, childs for children. (3) Simple addition ; the fishes doesn't live in the water.Misinformation errors are characterized by the use of the errors form of the morphemes of structure. While in omission is not supplied at 
all, in misinformation errors the students supply something although it is incorrect. The types of errors are: (1) Regularization of error ; the dog eated the chicken. (2/0 Archi-forms: I see her yesterday. Her dance with my brother. (3) Alternating form: I seen her yesterday. Misordering error is wrong placement of morpheme or a group of a morpheme in an utterance. For example: I don't know what that is.

\section{English Grammar}

Grammar has very important role to support writing. Having a goodgrammar style of a language will help learners to deliver ideas, messages andfeelings either to the listeners or readers.

Brown stated that, (2000) grammar is the system of rules governing the convectional arrangement relationship of word in a sentence. Meanwhile Nunan (2003) stated grammar is an essential resource in using language communicatively. while according to Pattel and Jain (2008:17), grammar is an attempt to develop concept, principles and rules relating to ussage and to the structure of language.

Knapp (2005) said Texts are always produced in a context. While texts are produced by individuals, individuals always produce those texts as social subjects; in particular, social environments.

According to Hyland (2009) a text is explicit not because it says everything all by itself but rather because it strikes a careful balance between what needs to be said and what may be assumed. The writere s problem is not just being explicit; the writer"s problem is knowing what to be explicit about. 16 Thus from the explanation above, It can be concluded text is produced by individuals and It is a passage that has composition on which a note is written, also it has structure and function.

\section{Narrative Text}

Knapp and Watkins (2005) said narrative is simply aboutentertaining a reading audience. It also has a powerful social role beyond that ofbeing a medium for entertainment. In other Elliot (2005) said narrative (story ) in the human sciences should be defined provisionally as discours with aclear sequential other that connect events in a meaningful way for a definiteaudience and thus offer insight about the world and or people ${ }^{\text {ee }}$ s experience of it. Mcintyre (2006) said narrative as basically a story, of happening or events, either real or imaginarywhich the narrator considers interesting or important. 


\section{Generic Structure of Narrative Text}

According to anderson (1997) Said there are four generic structure in narrative text namely orientation, evaluation, complication, resolution.

1. Orientation in which tells the audience about who is in the story, whenthe story is taking place and where the action happening.

2. Evaluation It explains the condition, behaviour, and the attitude of theparticipant.

3. Complication that sets off a chain of events that influences what will happen in the story.

4. Resolution in which the characters finnaly sort out the complication.

\section{Grammatical Features}

Besides having generic structure, narrative text also use significant grammatical features that support the form of a narrative text. Knapp (2005) said action verb, temporal connectives, past tense, reflection / evaluations, mentalverb, action verb metaphorically, rhytm, repetition. Anderson (2003) state that narrative usually include the following grammatical features: 1) nouns that identify the specific characters and places in the story, 2) adjectives that provide accurate description of the characters and setting, 3) time words that connect events to tell when they occur, 4) verbs that show the actions that occur in the story.

The primary rule for developing a sequence for introducing stories is to progress from simple stories to more complex stories. Factors to consider are (a) the number of characters, plots, goals, and sub-goals, (b) the number of attempts by characters to achieve the goal, (c) the explicitness of the story grammar components (the main characters, goal, and conflict), (d) the length of the story, (e) the readability of the story, and the amount of background knowledge required by students.

The purpose of a narrative, other than providing entertainment, can be to make the audience think about an issue, teach them a lesson, or excite their emotions. In well-written narration, a writer uses insight, creativity, drama, suspense, humor, or fantasy to create a central theme or impression. The details all work together to develop an identifiable story line that is easy to follow and paraphrase.

\section{RESEARCH METHOD}

Subject of research was at eleventh grade students at SMP SwastaTalitakum Medan. The number of students is 25 . To get the data of this research the writer gave test in writing narrativetext at tenth grade of SMP SwastaTalitakum Medan. The writer asked the students towrite English narrative using grammatical features and generic structure in a pieceof paper. The students were asked to write down narrative writing and the topic chosen by the writers. Then the students' assigmentwas collected. From this, the writers knew the common error made by the students in narrartive writing focused ongrammatical features ( simple past ) and generic structure. 
The writer gave test in narrative text at tenth grade of SMP SwastaTalitakum Medan, which will be focused on product in narrative text writing includes grammatical features and generic structure. The data are qualitatively will be analyzed by using the grammar of English. For method data analysis procedure the writer use descriptive qualitative. And the writer tries to describe the errors that made by the students when they write a subject. The writer tries to calculate the errors and make the reconstruction.After collecting the students' writing to determine the errors, the writer will do the next following steps as a part of data analysis. They are; 1) reading the students' writing to determine the errors, 2) analyzing the errors by underlining the error items, and classifying the errors based on surface strategy taxonomy by using special codes as follow; a) omission (OM), b) addition (AD), c) misformation (MF), d) misordering (MO)

\section{FINDING}

To know the test result, the writer made the table of students' errors that were taken from the data analysis. From the data calculation, the errors of misinformation are the most frequent errors in which the eleventh grade students at SMP SwastaTalitakumMedan committed 288 errors in regular verb. Moreover, it was followed by errors of misinformation with 156 errors, omission 56 errors, addition with 38 errors and misordering with 36 errors. Then errors in regular verb, it was followed by errors of misordering with 16 errors, omission with 29 errors, addition with 38 errors and misinformation with 150 errors.

The analysis below can be seen on the recapitulation table of the students' writing.

Table 1 The Student's Errors in Writing Focused on Simple Past Using Regular Verb Error Classification

\begin{tabular}{lllll}
\hline $\begin{array}{l}\text { Students' } \\
\text { Initial }\end{array}$ & Addition & Omission & Misinformation & Misordering \\
\hline A & 1 & - & 4 & 1 \\
\hline AP & 1 & 2 & 6 & - \\
\hline AT & 2 & 4 & 6 & 2 \\
\hline CAS & - & 3 & 5 & 2 \\
\hline DP & 1 & 4 & 3 & - \\
\hline FS & 2 & 2 & 6 & 4 \\
\hline FD & 3 & 3 & 5 & 3 \\
\hline GS & 1 & - & 6 & 2 \\
\hline GG & 2 & 3 & 8 & 1 \\
\hline HS & 1 & 3 & 10 & 3 \\
\hline HD & 3 & 1 & 6 & 5 \\
\hline IM & 1 & 4 & 7 & - \\
\hline
\end{tabular}




\begin{tabular}{lllll} 
IJ & 1 & 2 & 4 & 1 \\
\hline JM & 2 & 4 & 5 & 1 \\
\hline JN & 3 & 4 & 3 & 2 \\
\hline LL & 1 & 3 & 4 & 1 \\
\hline MM & 1 & 5 & 7 & - \\
\hline MG & - & 5 & 5 & - \\
\hline NN & 3 & - & 12 & 2 \\
\hline RYD & - & 2 & - & 1 \\
\hline RS & 2 & - & 6 & - \\
\hline Rsia & 1 & 1 & 13 & 2 \\
\hline SSia & 1 & - & 8 & 3 \\
\hline SSin & 3 & - & 11 & - \\
\hline SS & 2 & 3 & 6 & $\mathbf{3 6}$ \\
\hline Total & $\mathbf{3 8}$ & $\mathbf{5 6}$ & $\mathbf{1 5 6}$ & \\
\hline Total & & & & $\mathbf{2 8 8}$ \\
Error & & & & \\
\hline & & & &
\end{tabular}

$\mathrm{POM}=\underline{\text { Total Omission }} \mathrm{X} 100 \%=\underline{38} \mathrm{X} 100 \%=13.19 \%$

Total Error 288

$\mathrm{PAD}=\underline{\text { Total Addition }} \mathrm{X} 100 \%=\underline{56} \mathrm{X} 100 \%=19.44 \%$

Total Error 288

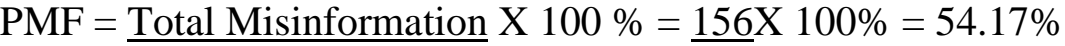

Total Error 288

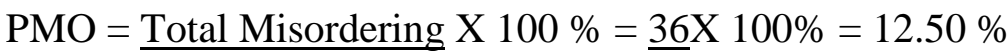

Total Error 288

Table 2 The Student's Errors in Writing Focused on Simple Past Using Irregular Error Classification

\begin{tabular}{lllll}
\hline Students' Initial & Omission & Addition & Misinformation & Misordering \\
\hline A & 2 & 2 & 7 & 1 \\
\hline AP & - & 1 & 6 & - \\
\hline AT & 1 & 1 & 6 & - \\
\hline CAS & 2 & 3 & 8 & 2 \\
\hline DP & - & 2 & 4 & - \\
\hline FS & 1 & 1 & 4 & 1 \\
\hline FD & 2 & 2 & 5 & 1 \\
\hline GS & - & 2 & 7 & - \\
\hline GG & 1 & 1 & 4 & 1 \\
\hline
\end{tabular}




\begin{tabular}{lllll} 
HS & 2 & 2 & 3 & - \\
\hline HD & 1 & 3 & 7 & 1 \\
\hline IM & - & 2 & 4 & 1 \\
\hline IJ & 2 & 1 & 6 & 3 \\
\hline JM & 1 & 2 & 2 & - \\
\hline JN & 2 & - & 9 & - \\
\hline LL & 2 & 2 & 6 & - \\
\hline MM & - & 1 & 6 & 2 \\
\hline MG & 2 & 1 & 9 & - \\
\hline NN & - & 1 & 7 & - \\
\hline RYD & 2 & 2 & 7 & 2 \\
\hline RS & 2 & 3 & 5 & - \\
\hline Rsia & - & 2 & 6 & 1 \\
\hline SSia & 1 & - & 11 & - \\
\hline SSin & 1 & - & 5 & - \\
\hline SS & 2 & 1 & 6 & $\mathbf{1 6}$ \\
\hline Total & $\mathbf{2 9}$ & $\mathbf{3 8}$ & $\mathbf{1 5 0}$ & \\
\hline Total Errors & & & $\mathbf{2 3 3}$ & \\
\hline
\end{tabular}

$\mathrm{POM}=\underline{\text { Total Omission }} \mathrm{X} 100 \%=\underline{29} \mathrm{X} 100 \%=12.45 \%$

Total Error

233

$\mathrm{PAD}=\underline{\text { Total Addition }} \mathrm{X} 100 \%=\underline{38} \mathrm{X} 100 \%=16.31 \%$

Total Error 233

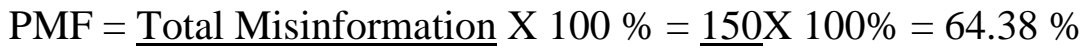

Total Error

233

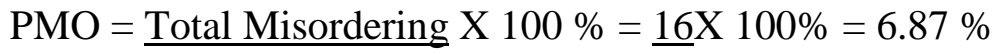

Total Error

233

Based on the table of students' error in writing, it can be stated that:

1. Total errors of omission using regular verb are $13.19 \%$

2. Total errors of addition using regular verb are $19.44 \%$

3. Total errors of misinformation using regular verb are $54.17 \%$

4. Total errors of misordering using regular verb are $12.50 \%$

5. Total errors of omission using irregular verb are $12.45 \%$

6. Total errors of addition using irregular verb are $16.31 \%$

7. Total errors of misinformation using regular verb are $64.38 \%$

8. Total errors of misordering using regular verb are $6.87 \%$ 
Table 3 Students' Errors in Simple Past

\begin{tabular}{llll}
\hline Error Classification & & & \\
\hline Students' Initial & Regular & Irregular & Total \\
\hline A & 1 & 3 & 4 \\
\hline AP & 1 & 5 & 6 \\
\hline AT & 3 & 3 & 6 \\
\hline CAS & 1 & 2 & 3 \\
\hline DP & 1 & 4 & 5 \\
\hline FS & 3 & 2 & 5 \\
\hline FD & - & 6 & 6 \\
\hline GS & 3 & 3 & 6 \\
\hline GG & 4 & 3 & 7 \\
\hline HS & 2 & 1 & 3 \\
\hline ID & 1 & 5 & 6 \\
\hline IM & 3 & 2 & 5 \\
\hline JJ & 1 & 2 & 3 \\
\hline JN & 3 & 1 & 4 \\
\hline LL & 3 & 1 & 4 \\
\hline MM & 2 & 2 & 4 \\
\hline MG & 1 & 2 & 3 \\
\hline NN & 2 & 5 & 7 \\
\hline RYD & 3 & 4 & 7 \\
\hline RS & 1 & 3 & 4 \\
\hline Rsia & 2 & 3 & 5 \\
\hline SSia & - & 5 & 5 \\
\hline SSin & - & 6 & 6 \\
\hline SS & 2 & 2 & 4 \\
\hline Total & 2 & 1 & 3 \\
\hline & $\mathbf{4 5}$ & $\mathbf{7 6}$ & $\mathbf{1 2 1}$ \\
\hline
\end{tabular}

Table 4 Percentage of Students' Narrative Writing Focused on Simple Past

\begin{tabular}{lll}
\hline No & Form of Simple Past Tense & Percentage \\
\hline 1 & Regular Verb & $37.19 \%$ \\
\hline 2 & Irregular Verb & $62.81 \%$ \\
\hline \multicolumn{2}{l}{ Total } & \\
\hline
\end{tabular}


Regular Verb $\underline{45}$ X $100 \%=37.19 \%$

121

Irregular Verb $\underline{76} \times 100 \%=62.81 \%$

121

In preceding the explanation, the data were taken from students' answer sheet. Then the writer classified the students' errors in narrative writing on simple past using regular verb and irregular verb, as simple past is used in narrative writing. The writer only focused on; 1) omission, 2) addition, 3) misinformation, 4) misordering. After classifying the students' errors, of narrative writing focused on simple past tense and explaining the frequency of errors in simple past tense, the following table describes the high frequency of errors.

Table .5 The Sequence of Errors in Writing Focused on Simple Past Based on Its High Frequency of Error

\begin{tabular}{lll}
\hline No & Form of Simple Past Tense & Percentage \\
\hline 1 & Regular Verb & $37.19 \%$ \\
\hline 2 & Irregular Verb & $62.81 \%$ \\
\hline
\end{tabular}

The table above showed that the highest frequency of errors was made by Ninth grade of SMP SwastaTalitakum Medan, the highest errors in narrative writing focused on simple past is irregular verb $62.81 \%$ and the lower is regular verb $37.19 \%$.

\section{DISCUSSION}

After conducting the research, the writer got the result. The students still had difficulties in writing narrative text. The writer got the data about the students' errors that are commonly made in writing narrative text by using simple past. Based on Brown's theory, the writers classified the errors made the students, namely Misinformation, addition, omission, and misordering. From the data, The Student's Errors in writing focused onSimple Past Using Regular Verb, the higher errors are misinformation (54.17\%), followed by addition (19.44\%), and omission (13.19\%), then followed by misordering $(12.50 \%)$. The Student's errors in writing focused on Simple Past Using Irregular, the higher errors are misinformation $(64.38 \%)$, then followed by addition $(16.31 \%)$, then omission (12.45\%), and followed by misordering $(6.87 \%)$.

This problem was found by the researchers based on the result of errors analyzed with observation checklist. There were many factors that influenced errors in their writing. Error analysis is important because this method could help English teacher found the next media or technique to teach writing and help 
students if they found difficulties in made paragraph. Error analysis is tool to help the researcher checked the grammatical error that made by students especially using tenses in narrative text. 39 Based on the previous study that used by researchers from Wati (2011), the researchers found that the result from Wati (2011) An error analysis is important to describe what kinds of error that students made because every student have different mistake when they made a paragraph and how students could learn from their mistake as a English teacher Error analysis is important to correct their method when they taught

Then, based on Syarif (2014) the researcher found Error analysis is the process of language learning for analyzing, observing, interpreting and classifying learner's error to give us indication in learning pocess especially in past continuous. According to Hourani (2008) error analysis is an essential source of information to teachers. It provides information on students' errors which in turn helps teachers to correct students' errors and also improves the effectiveness of their teaching". The correlation between result of reseachers' finding and previous study, there were discused the importance of error analysis are this method could help English teacher found the next media or technique to teach writing and help students if they found difficulties in made paragraph. This theory is supposed by the previous study that described about error analysis had important role to find a solution by the teacher about what they to do next in explaining the material especially writing paragraphs and for the students of error analysis could be used material correction of their task. Therefore, if the students got writing task, they did not make same mistake.

\section{CONCLUSION}

Based on the analysis and description of data in previous chapter, it can be concluded that after analyzing through the research, the writer got the data about students' errors, which are commonly made in narrative writing using simple past. The students' errors are Misinformation, Addition, Omission and Misordering.

\section{REFERENCES}

Anderson \& Cathy, A. (1997). Text Types in English. South Yarra: McMillan Andrew. (2015). To Be or Not to Be Superstitious-That's the Question. Perak. Elsevier.

Bootchuy, T. (2008) An Analysis of Error in Academic English Writing by a Group of First-year Thai Graduates Majoring in English. (Master's Thesis) Kasetsart Unversity, Thailand.

Brown, H D. (2000). Principles of Language Learning and Teaching. New York: Prentice-Hall, Inc.

Corder, S. P. (1981). Error Analysis and Interlanguage. London: Oxford University Press. 
Dulay, H. (1982). Language Two. Oxford : Oxford University Press.

Edge, J. (1997). Mistakes and correction. London: Longman.

Elliot, J. (2005). Using Narrative in Social Research. Qualitative and Quantitative Approaches. London. Sage Publications

G. J. Taylor, R. M. Bagby, J. D. A. \& Parker (1997). Disorders of Affect Regulation: Alexithymia in Medical and Psychiatric Illness (Paperback edition 1999). Cambridge University Press. ISBN 0- 521-77850.

Harmer, J. (2007). The Practice of English Language Teaching. New York. Pearson Longman.

Herlinawati. (2011). Error Analysis In The Students Writing Narrative Paragraphj at MTsN Pajajaran Pamulang (Thesis: State Islamic University Syarif Hidayatullah, Jakarta)

Hourani, T. M. (2008). An Analysis of the Common Grammatical Errors in the English Writing Made by 3rd Male Secondary Students in the Eastern Coast of the UAE, Dissertation, Institute of Education, British University in Dubai.

Ken, H, \& Continuum. (2009). Academic Discourse: English in a Global Context. London. Elsevier.

Knapp, P \& Watkins, M. (2005). Genre and Grammar. Sidney: UNSW Press.

Linse \& Caroline T. (2005). Practical English Language Teaching: Young Learners. New York. McGraw-Hill Companies, Inc.

McIntyre \& Busse. (2005). Language and Style. Red Globe Press.

Nunan, D (ed), (2003). Practical English Laguage Teaching. New York: McGraw-Hill.

Pattel, J. (2008). English Language Teaching (Methods, Tools \& Techniques). Jaipur. Sunrise Publishers \& Distributors.

Sattayatham, A \& Ratanapinyowong, P. (2008). Analysis of Errors in Paragraph Writing in English by First Year Medical Students from the Four Medical Schools at MahidolUniversit. Silpakorn University International Journal $8(3): 17-38$.

Spillner, B. (1991) Error Analysis. A Comprehensive Bibliographz. Amsterdam/ P hiladelphia. John Banjamins.

Syarif, R., R. (2014). An Error Analysis On Students' Simple Past Tense Mastery In Their Narrative Text (A Case Study at the Eleventh Grade Students of SMAN 4 Bekasi. Thesis, State Islamic University Syarif Hidayatullah Jakarta

Wati, H. (2011). Error Analysis In The Students Writing Narrative Paragraph At MTSN Panjajaran (Thesis, State Islamic University Syarif Hidayatullah, Jakarta). Retrieved from http: //repository.uinjkt.ac.id/dspace/ 